\title{
Nickel Supported Natural Zeolite as a Bifunctional Catalysts for Conversion of Citronella Oil Crude to Menthols
}

\author{
Ralentri Pertiwi ${ }^{1}$, Silvester Tursiloadi ${ }^{2, *}$, Indri Badria Adilina ${ }^{2}$, Kiky Cornelia Sembiring ${ }^{3}$ and Yuya \\ Oaki $^{4}$ \\ ${ }^{1}$ Department of Chemistry, Faculty of Mathematic and Natural Sciences, University of Indonesia, Kampus UI \\ Depok, Indonesia \\ ${ }^{2}$ Research Centre for Chemistry, Indonesian Institute of Sciences Kawasan PUSPIPTEK Serpong, Tangerang, \\ 15314 , Indonesia \\ ${ }^{3}$ Graduate School of Energy Science, Kyoto University, 606-8501 Sakyo-ku, Kyoto, Yoshidahon-cho, Japan \\ ${ }^{4}$ Department of Applied Chemistry, Faculty of Science and Technology, Keio University, Japan \\ *Corresponding Author: tursiloadi@yahoo.com
}

\begin{tabular}{l} 
A R T I C L E I N F O \\
\hline Article history \\
Received date : 31 October 2016 \\
Revised date : 5 December 2016 \\
Accepted date : 5 January 2017 \\
Available online at \\
http://kimia.lipi.go.id/inajac/index.php \\
Keywords: \\
Natural Zeolite, Nickel Catalyst, \\
Citronella Oil, Menthol \\
\end{tabular}

\section{INTRODUCTION}

Citronella oil is the main product of Java citronella grass (Cymbopogon winterianus Jowitt) widely used in cosmetics, fuel additives and pharmaceuticals industries. It has three main components; citronellal, citronellol, and geraniol. Indonesia as one of the world's largest producers of citronella oil has produced approximately 350 tons of citronella oil annually [1]. The derivatives of citronella oil can provide high value added chemicals for many industries such as menthol. Synthesis of menthol from citronellal can be performed through a two-step reaction, first, cyclization of citronellal to isopulegol over an acid catalyst, and the second, hydrogenation process to menthol over a metal catalyst.

Zeolite is a crystalline solid structure composed by tetrahedral alumina $\left(\mathrm{AlO}_{4}{ }^{5-}\right)$ and silicate $\left(\mathrm{SiO}_{4}{ }^{4-}\right)$. Zeolite can be divided into two types, natural zeolite which contains several cations such as $\mathrm{K}^{+}, \mathrm{Na}^{+}, \mathrm{Ca}^{2+}$ or $\mathrm{Mg}^{2+}$ and synthetic zeolite which mainly only contains $\mathrm{K}^{+}$ or $\mathrm{Na}^{+}$cations [2]. Brönsted acid sites are formed and may modify zeolites into solid acid catalysts. Indonesia has an abundant natural zeolite source spread out in Java, NTT, Papua, Sumatra, Sulawesi, and Borneo. The highest deposit of zeolite was recorded up to 400 million tons in West Java with mordenite and clinoptilolite as the common types in this area.

$\mathrm{Ni} / \mathrm{ZnBr} / \beta$-zeolite can transform citronellal to isopulegol and menthol in a one pot reaction system, with a selectivity to isopulegol of $73.8 \%$ and menthol of $6.40 \%$ [3]. The presence of $\mathrm{Ni}$ sites played the role of Lewis acid sites, which can initiate an intermolecular carbonyl and cyclization mechanism. Adilina, et al. (2015) used nickel supported natural zeolites (Ni/NZ) as catalysts in a two stage reaction of citronellal to menthols. Preparation of catalyst using an ion exchange method was able to convert citronellal derivatives to $9 \%$ menthol with $36 \%$ selectivity [4].

In this study, natural zeolite was designed as catalysts for the green conversion of citronella oil to menthol. These catalysts was prepared through modification of natural zeolite with $\mathrm{Ni}$ 
metal, and therefore it was expected to have bifunctional catalytic properties; acid site (metal oxide in natural zeolite) and hydrogenation site (Ni metal), which are required for conversion of citronella oil derivatives compounds. Immobilization of Ni metal will be performed by impregnation method and various reaction parameters will be studied. With this study, local natural zeolites may participate in green technology which provides a significant role in national development, both as a prime export commodity mining and raw material in the domestic industries. In addition, the synthesis of menthol provides a product of high value from Indonesia citronella oil.

\section{EXPERIMENTAL SECTION}

\subsection{Catalyst Preparation Characterization}

and

Natural zeolite used in this experiment was taken from Bogor, Indonesia. This zeolite with the sizes of 200 mesh contain $\mathrm{SiO}_{2}$ higher than $\mathrm{Al}_{2} \mathrm{O}_{3}$ as previously reported [4]. Acidified Natural Zeolite (NZB) was prepared through acid activation using $\mathrm{HCl} 1 \mathrm{M}$ and stirring for 1 $\mathrm{h}$. The solution was filtrated and rinsed with distilled water until the solution was neutral $(\mathrm{pH}$ : 6-7). The activated zeolite was then dried at $250^{\circ} \mathrm{C}$ for $3 \mathrm{~h}$ and used as catalyst support.

Nickel supported natural zeolite $(\mathrm{Ni} / \mathrm{NZB})$ was prepared by impregnation method at $80^{\circ} \mathrm{C}$ with ethanol solutions containing $20 \mathrm{wt} \% \mathrm{Ni}$ from $\mathrm{Ni}\left(\mathrm{NO}_{3}\right)_{2} \cdot 6 \mathrm{H}_{2} \mathrm{O}$ salt. The solution was stirred until the solvent was slowly removed. After the impregnation, the resulting $\mathrm{Ni} / \mathrm{NZB}$ was dried at $120^{\circ} \mathrm{C}$ for $2 \mathrm{~h}$. Calcination was conducted at $500^{\circ} \mathrm{C}$ for $2 \mathrm{~h}$ and then reduced with $\mathrm{H}_{2}$ flow at $300^{\circ} \mathrm{C}$ for $2 \mathrm{~h}$. For comparison, another catalysts was directly reduced (without calcination) with $\mathrm{H}_{2}$ flow at $300^{\circ} \mathrm{C}$ for $2 \mathrm{~h}$. The specific surface area, pore size distribution, and pore volume of samples were estimated by the Barret-Joyner-Halenda (BJH) method using $\mathrm{N}_{2}$ adsorption-desorption curves (Micromeritic TriStar II, Flow Prep 060), Crystallization behaviors of the samples were investigated with X-ray diffractometer (Rigaku Smart Lab 3kW XRay Diffractometer, $\mathrm{Cu} \mathrm{K} \alpha$ Radiation). Alteration in the microstructure of samples during heating were discussed using Thermogravimetric Analysis and Differential Scanning Calorimetric TG-DSC (Linseis STA PT 1600), and the grain sizes of the samples were estimated from the images observed by TEM (FEI type Tecnai G2 20S-Twin).

\subsection{Catalytic Activity}

The conversion of citronella oil was carried out in a $200 \mathrm{~mL}$ autoclave by heating 6.5 mmol citronella oil and $\mathrm{Ni} / \mathrm{NZB}$ catalysts at $200^{\circ} \mathrm{C}$ for $3 \mathrm{~h}$ by stirring at a pressure of $20 \mathrm{bar}$ $\mathrm{H}_{2}$. The amount of catalyst was varied between $5 \mathrm{wt} \%$ and $10 \mathrm{wt} \%$ of reactant. The products were analyzed by GC-Mass Spectrometry (Agilent 19091S, column HP-5MS (30 m x 250 $\mathrm{m}, 0.25 \mathrm{~m})$ ).

\section{RESULT AND DISCUSSION}

\subsection{Preparation and Characterization of Catalysts}

The presence of elements such as $\mathrm{K}^{+}, \mathrm{Na}^{+}$, $\mathrm{Ca}^{2+}$ or $\mathrm{Mg}^{2+}$ in the zeolite surface can affect activity of zeolite used in the reaction (Table 1). Pretreatment, such as milling, heating and acid tretment, is necessary to improve the character of natural zeolite. In this research, activation of natural zeolite performed by an ion exchange method using $\mathrm{HCl} 1 \mathrm{M}$ at room temperature for 1 hour replacing several ions such as $\mathrm{K}^{+}, \mathrm{Na}^{+}$, $\mathrm{Ca}^{2+}$ or $\mathrm{Mg}^{2+}$ with $\mathrm{H}^{+}$(Lewis acid site) which is required in the cyclization reaction of citronellal. Yilmaz, et al. (2005) reported that the presence of $\mathrm{Fe}$ as an impurity and the electrostatic field produced by the constituent ions (e.g., $\mathrm{Na}, \mathrm{K}$ ) being part of the zeolite structure was reported to improve the selectivity to unsaturated alcohols (citronellol) [5].

Table 1. Chemical composition of natural zeolite (NZB)

\begin{tabular}{cc}
\hline Component & \% \\
\hline $\mathbf{S i O}_{2}$ & 72.27 \\
\hline $\mathbf{A l}_{2} \mathbf{O}_{3}$ & 14.74 \\
\hline $\mathbf{K}_{2} \mathbf{O}$ & 5.30 \\
\hline $\mathbf{C a O} \mathbf{O}$ & 3.41 \\
\hline $\mathbf{F e}_{2} \mathbf{O}_{3}$ & 2.41 \\
\hline Others & 1.87 \\
\hline
\end{tabular}


In addition, activation of zeolite will dissolve inorganic ions on the surface of the natural zeolite. The increase of surface area of zeolite was observed after acid treatment using $\mathrm{HCl}$ (Table 2). The average pore diameter of zeolites in the range of $>2 \mathrm{~nm}$ indicates that the natural zeolite is dominated with mesoporous (2 $\sim 50 \mathrm{~nm}$, IUPAC).

Table 2. Specific surface area, pore volume, and pore size distribution of samples

\begin{tabular}{lccc}
\hline Samples & $\begin{array}{c}\text { Surface } \\
\text { Area } \\
\left(\mathbf{m}^{\mathbf{2}} \mathbf{g}^{-1}\right)\end{array}$ & $\begin{array}{c}\text { Pore } \\
\text { Volume } \\
\left(\mathbf{c m}^{\mathbf{3}} \mathbf{g}^{-1}\right)\end{array}$ & $\begin{array}{c}\text { Average } \\
\text { Pore } \\
\text { Diameter } \\
(\mathbf{n m})\end{array}$ \\
\hline $\mathbf{N Z B}$ & 16 & 0.004 & 2.11 \\
\hline $\begin{array}{l}\text { NZB- } \\
\text { actived }\end{array}$ & 78 & 0.006 & 2.07 \\
\hline Ni/NZB & 17 & 0.003 & 2.08 \\
\hline $\begin{array}{l}\text { Ni/NZB- } \\
\text { CL }\end{array}$ & 29 & 0.004 & 2.08 \\
\hline $\begin{array}{l}\text { Ni/NZB- } \\
\text { CLHT }\end{array}$ & 29 & 0.003 & 2.08 \\
\hline $\begin{array}{l}\text { Ni/NZB- } \\
\text { HT }\end{array}$ & 37 & 0.005 & 2.08 \\
\hline
\end{tabular}

Note: CL: calcination, CLHT: calcination-reduction, HT: reduction

The immobilization of Ni metal in natural zeolites have been reported by using an impregnation method. $\mathrm{Ni}$ is inexpensive and widely known for good activity in hydrogenation reactions. However, the active sites of the zeolite does not have a large surface area. The reaction becomes ineffective and inefficient because all active centers are not able to contact with the reactants. Therefore, the Ni metal is required to be distributed on a solid support with a large surface area like zeolite [6]. In this study, $\mathrm{Ni} / \mathrm{NZB}$ catalysts were synthesized using 20 wt $\%$ of Ni metal. Ni was expected to increase the activity of the catalyst in the hydrogenation of citronellal reaction. We also observed the differences in characteristics and activity of the catalysts which was synthesized through calcination and hydrogen treatment (CLHT) processes compared with direct hydrogenation process on catalyst without calcination (HT).

The specific surface area, pore volume, and pore size distribution of samples were estimated by the Barret-Joyner-Halenda (BJH) method using $\mathrm{N}_{2}$ adsorption-desorption curves. Table 2 shows the comparison of NZB before and after activation using $\mathrm{HCL}$, and $\mathrm{Ni} / \mathrm{NZB}$ catalysts. The surface area of the $\mathrm{Ni} / \mathrm{NZB}$ catalysts decreased compared to the acitivated NZB. This is possible because the Ni metal was entrusted to the buffer and covered the surface of the zeolite pores. After calcination, the surface area of zeolite increased. The calcination stage used a relatively high temperature hence the distribution of $\mathrm{Ni}$ on the surface of the pores was evenly distributed to form the oxide. Other compounds such as $\mathrm{NO}_{2}, \mathrm{O}_{2}, \mathrm{H}_{2}$ which were trapped in the pores of the catalyst were able to be released in this phase. The surface area of $\mathrm{Ni} / \mathrm{NZB}-\mathrm{HT}$ was observed to be the highest.

The XRD pattern of NZB and Ni/NZB catalysts were given in Figure 1(a). Characteristic peaks of mordenite $\left(2 \theta=9.84^{\circ}\right.$, $13.48^{\circ}, 22.34^{\circ}, 25.74^{\circ}, 26.66^{\circ}, 27.68^{\circ}$ ) phases were detected in the NZB structure. A high peak intensity at $2 \theta=26.66^{\circ}$ indicated that mordenite was the main constituent mineral, although a few clinoptilolite peaks $\left(2 \theta=11.2^{\circ}, 19.72^{\circ}, 22.42^{\circ}\right.$, $25.82^{\circ}, 27.92^{\circ}$ ) was observed. When compared to the Ni/NZB catalysts, there was no change in the value of $2 \theta$. After the immobilization with $\mathrm{Ni}$, the intensity of these peaks increased. Therefore, it can be assumed that the calcination process was able to remove impurities in the framework of zeolite.

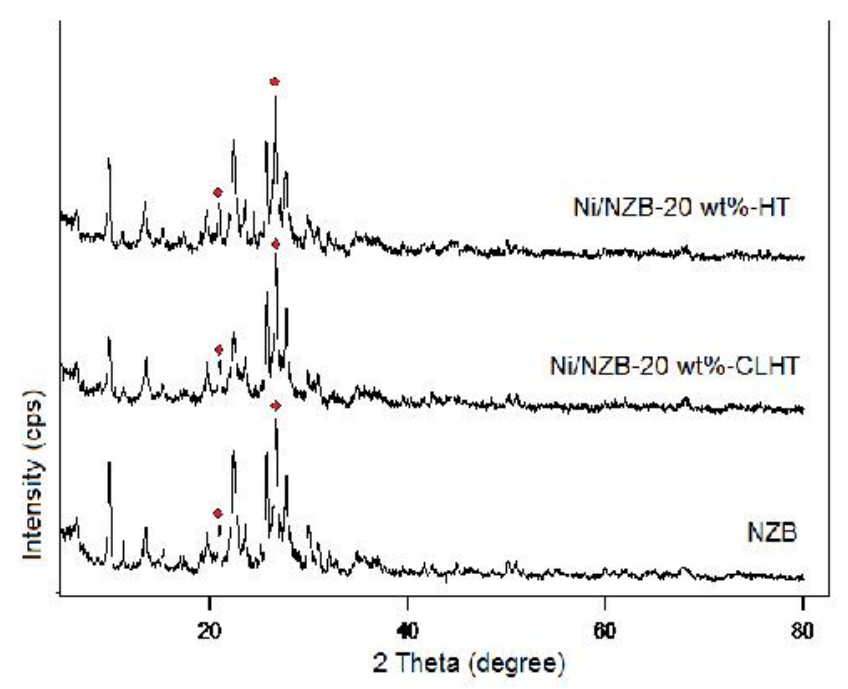

(a) 
pp. 132-138, December 2016

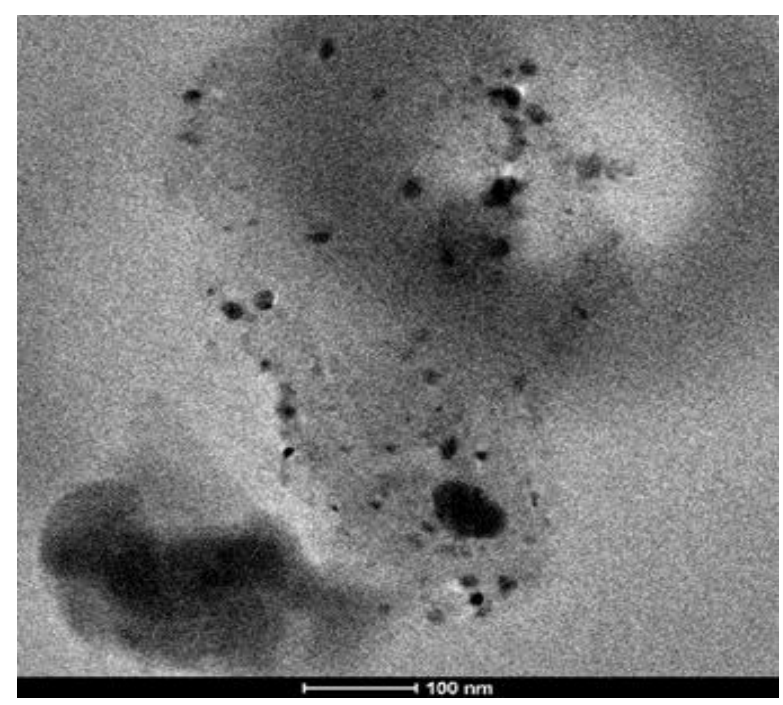

(b)

Fig. 1. (a) Diffractograms of catalyst samples, (b) TEM image of the Ni/NZB-HT catalyst.

Figures 1(b) shows the TEM image of the Ni/NZB catalyst. The Ni particles were well dispersed over the NZB support, confirmed by the observation of black dots with small grains, around $12.5 \mathrm{~nm}$ in diameter. These particles should be exclusively localized on the outer surface of the zeolite crystallites.

Results of TG/DSC profile is shown in Figure 2. A weight lost of the catalyst at a temperature of $80^{\circ} \mathrm{C}$ accompanied by endothermic peak may be attributed to evaporation of water on the catalyst. Meanwhile, an exothermic peak at around $580^{\circ} \mathrm{C}$ and a weight loss of $14 \%$ indicated that the evaporation of crystal water and combustion of residual organic compounds in the zeolite structure. The water content in the catalyst was also calculated based on the changes in mass at temperatures between $30{ }^{\circ} \mathrm{C}-120{ }^{\circ} \mathrm{C}$, which was up to $7 \%$. The increase in mass of the catalyst shown at the temperature $>580^{\circ} \mathrm{C}$, indicated that oxidation reaction occurs in the $\mathrm{Ni}$ metal with oxygen from the air to form $\mathrm{NiO}$ compound [7]. According to the results, the temperature of calcination was reached at $500^{\circ} \mathrm{C}$. Extending the heating time over $2 \mathrm{~h}$ can eliminate the organic compounds contained in pore of the catalyst.

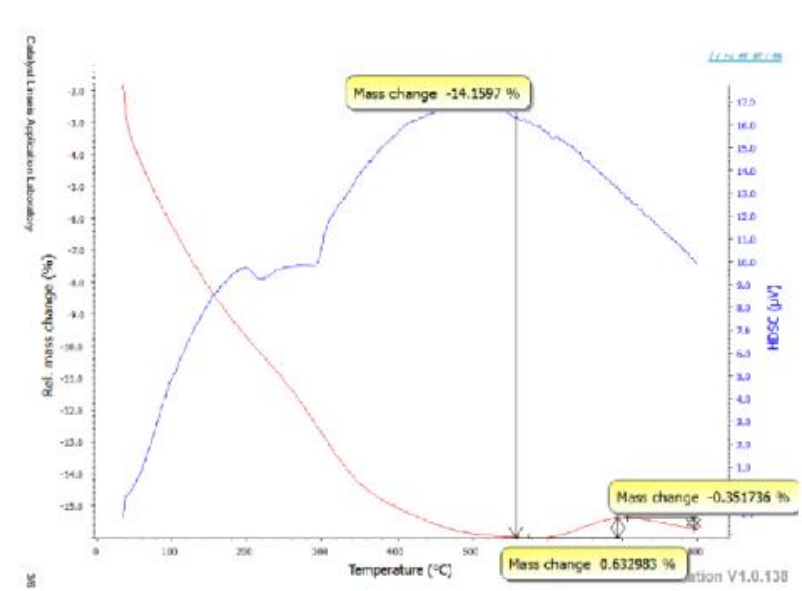

Fig. 2. TG/DSC profile of Ni/NZB catalyst

\subsection{Conversion of citronella oil to menthol}

The cyclization-hydrogenation reactions of citronella oil in a one-pot reaction system was carried out in an autoclave by heating at $200^{\circ} \mathrm{C}$ temperature for 3 hours with 20 bar of $\mathrm{H}_{2}$ pressure. Citronella oil used in the reactions was the result of fractionation distillation of citronella oil with $>60 \%$ citronellal content as well as other components such as linalool and citronellol. Isopulegol is an intermediate compound of the cyclization of citronellal in the presence of an acid catalyst (Scheme 1).

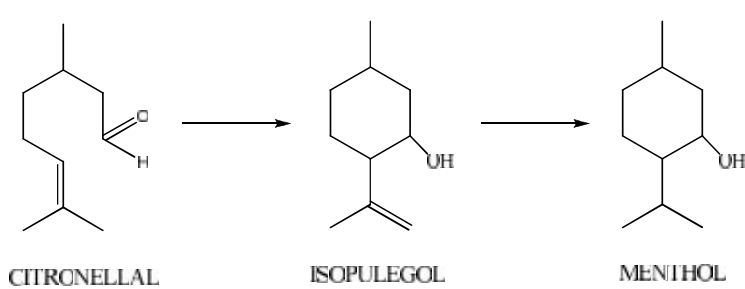

Scheme 1. (i) cyclization of citronellal to isopulegol, (ii) hydrogenation of isoeugenol to menthol.

The $\mathrm{C}=\mathrm{C}$ and $\mathrm{C}=\mathrm{O}$ bond of citronellal was destabilized due to the high acidity of the catalyst where an interaction between electrons on the carbonyl and $\pi$ electrons on the $\mathrm{C}=\mathrm{C}$ bond with the Lewis acid site catalyst occurred and accompanied by protonation of the Brönsted acid to form isopulegol. According to Chuah et al. (2001), the catalyst having a weak Brönsted acid site and higher Lewis acid site will have a high selectivity in cyclization reaction of citronellal 
[8]. Almost all the catalytic activity of the $\mathrm{Ni} / \mathrm{NZB}$ catalysts in this study resulted the isopulegol compound with yield of $>4 \%$ (Table 3). Catalysts Ni/NZB-CLHT-5 with amount of 5 wt $\%$ catalyst was able to selectively form isopulegol up to $50 \%$ (50\% selectivity). The lowest yield of isopulegol was achieved by using Ni/NZB-HT-10 catalyst, however, a higher yield of menthol was observed. This is possible due to most of the isopulegol compounds are hydrogenated into menthols.

Citronellal has two active functional groups which is attached to the carbonyl $\mathrm{C}$ atom and double bond $(\mathrm{C}=\mathrm{C})$. The existence of carbonyl $(\mathrm{C}=\mathrm{O})$ in citronellal allow hydrogenation reactions to form compounds that produce citronellol alcohol group (C-OH). A highly acidic catalyst may directly yield products of hydrogenated citronellal, citronellol and 3,7dimethyl-1-octanol, as a result of their interaction with the metal $\mathrm{Ni} \pi$ bond.

Conversion of citronellal oil was performed using two different amount of catalyst to reactants, i.e. $5 \mathrm{wt} \%$ and $10 \mathrm{wt} \%$. Product analysis by GC-MS is shown in Table 3. From these results, it was observed that the Ni/NZBHT-10 catalyst with $10 \mathrm{wt} \%$ amount of catalyst was able to produce menthol compounds up to $50 \%$ selectivity. On the other hand, the yield of menthol (12\%) was lower using Ni/NZB-HT-5 catalyst. This is probably due to the lack of $\mathrm{Ni}$ metal active site in Ni/NZB-HT-5 compared to $\mathrm{Ni} / \mathrm{NZB}-\mathrm{HT}-10$ which plays an important role in the hydrogenation of isopulegol to menthol.

The effect of temperature was performed at $100^{\circ} \mathrm{C}, 200^{\circ} \mathrm{C}$, and $300^{\circ} \mathrm{C}$. The product distributions slightly changed with the increase of temperature for a given conversion. In the beginning, citronellal was converted to $50 \%$ isopulegol but no menthol was formed. This was due to the formation of undesirable products of catalytic cracking of isopulegol at high temperatures. The cyclic structure of isopulegol seems to easily decompose in higher reaction temperatures yielding byproducts other than the desired menthol.

Table 3. GC-MS Analysis result for Conversion of Citronella Oil to Menthols.

\begin{tabular}{lcccccc}
\hline \multicolumn{1}{c}{ Catalyst } & $\begin{array}{c}\text { Conversion } \\
(\mathbf{\%})\end{array}$ & $\begin{array}{c}\text { Yield } \\
\text { Citronelol } \\
(\boldsymbol{\%})\end{array}$ & $\begin{array}{c}\text { Yield } \\
\text { Isopulegol } \\
(\boldsymbol{\%})\end{array}$ & $\begin{array}{c}\text { Yield } \\
\text { Menthol } \\
(\boldsymbol{\%})\end{array}$ & $\begin{array}{c}\text { Yield } \\
\text { Others } \\
(\boldsymbol{\%})\end{array}$ & $\begin{array}{c}\text { Selectivity } \\
\text { of Menthol } \\
(\boldsymbol{\%})\end{array}$ \\
\hline NZB-5 & 100 & 0 & 12 & 0 & 88 & 0 \\
NZB-10 & 100 & 0 & 10 & 0 & 90 & 0 \\
Ni/NZB-HT-5 & 100 & 4 & 41 & 12 & 43 & 12 \\
Ni/NZB-HT-10 & 100 & $\mathbf{5}$ & $\mathbf{1 0}$ & $\mathbf{5 0}$ & $\mathbf{3 5}$ & $\mathbf{5 0}$ \\
Ni/NZB-CLHT- & 100 & 1 & 50 & 0 & 49 & 0 \\
5 & & 1 & 18 & 18 & 63 & 18 \\
Ni/NZB-CLHT- & 100 & & & & & \\
10 & & & 5 & 0 & 46 & 0 \\
Ni/NZB-HT-10 & 51 & 5 & 4 & 14 & 77 & 14 \\
\hline Ni/NZB-HT-10 & 100 & 5 & & & & \\
\hline
\end{tabular}

Reaction conditions: 1 gr citronella oil, $200^{\circ} \mathrm{C}, 3$ hours, 20 Bar, CLHT: calcination-reduction; HT : reduction, Amount of catalysts 5: $5 \mathrm{wt} \%$, 10: $10 \mathrm{wt} \%$, Variety of temperature: ${ }^{\mathrm{a}} 100^{\circ} \mathrm{C},{ }^{\mathrm{b}} 300^{\circ} \mathrm{C}$. 


\section{CONCLUSION}

The nickel supported on zeolite catalysts played a role as a bifunctional catalyst for the one-pot transformation of citronellal to menthols at $200{ }^{\circ} \mathrm{C}$ with pressure of 20 bar $\mathrm{H}_{2}$ for $3 \mathrm{~h}$. These catalysts were prepared from natural zeolite by acid activation and immobilization of Ni metal using an impregnation method. High activity and selectivity for $50 \%$ isopulegol was reached using the Ni/NZB-CLHT catalytst which was synthesized by a calcinationhydrogen treatment process. Meanwhile Ni/NZB-HT catalyst which was synthesiszed by direct hydrogenation treatment showed the highest activity and selectivity for menthol ranging up to $50 \%$. A lower catalytic activity giving only $51 \%$ conversion of citronellal was seen using the Ni/NZB-HT catalyst when the reaction temperature was lowered to $100{ }^{\circ} \mathrm{C}$. On the other hand, increasing the temperature to 300 ${ }^{\circ} \mathrm{C}$ gave high conversion of $100 \%$ but mainly resulted undesirable catalytic cracking products. These nickel supported on zeolite catalysts are therefore promising materials for the conversion of citronella oil to value added flavor chemicals especially menthols.

\section{ACKNOWLEDGMENT}

This research was supported by the Competitive Grant of Research Centre for Chemistry and the Research Centre for Physics, Indonesian Institute of Sciences (LIPI) fiscal Year 2015, and are gratefully acknowledged.

\section{REFERENCES}

[1]. National Agency for Export Development (NAFED). Export News Indonesia. February 2008, vol.1, No.II. National Agency for Export Development (NAFED).

[2]. A.M Fuadi, M. Musthofa, K. Harismah, Haryanto, N. Hidayanti. (2013). "Pemakaian microwave untuk optimasi pembuatan zeolite sintetis dari abu sekam padi" In Proceedings of the Eighth International Joint Conference on Artificial Intelligence, 2013, pp. 556-560.
[3]. N. Khoirun, D.I. Elvina, T.T. Rachmat, "One-pot transformation of $(R)-(+)$ citronellal over a bifunctional $\mathrm{Ni} / \mathrm{ZnBr}_{2} / \beta$ zeolite catalyst" 2013, Makara Journal of Science, vol. 17, No. 3, In Press.

[4]. I.B. Adilina, R. Pertiwi, A. Sulaswatty, "Conversion of ( \pm -citronellal and its derivatives to (-)-menthol using bifunctional nickel zeolite catalysts" Biopropal Industry, 2015, vol. 6, No. 1, pp. 1-6.

[5]. S. Yilmaz, S. Ucar, A. Levent, G. Hilal, "The kinetics of citral hydrogenation over Pd supported on clinoptilolite rich natural zeolite" Applied Catalysis A: General, 2005, vol. 287, pp. 261-266.

[6]. B. Ridla, U. Tresye, P.S. Indra, "Kaolin sebagai Sumber $\mathrm{SiO}_{2}$ untuk Pembuatan Katalis $\mathrm{Ni} / \mathrm{SiO}_{2}$ : Karakterisasi dan Uji Katalis pada Hidrogenasi Benzena Menjadi Sikloheksana" Makara Journal of Science. vol. 12, No. 1, pp. 40.

[7]. S. Tursiloadi, " Mesoporous oxide materials based on the sol-gel method. Germany: Lambert Academic Publishing" 2010.

[8]. G.K. Chuah, S.H. Liu, S. Jaenicke, L.J. Harrison. "Cyclisation of citronellal to isopulegol catalysed by hydrous zirconia and other solid acids" Journal of Catalysis, 2001, vol. 200, 356. 